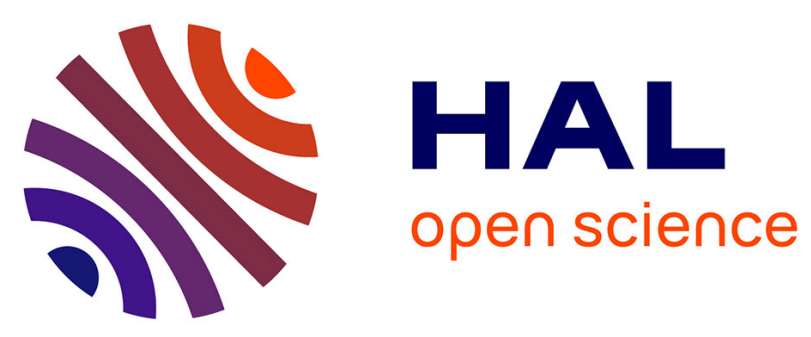

\title{
Bioaccessibility of selenium after human ingestion in relation to its chemical species and compartmentalization in maize
}

Stéphane Mombo, Eva Schreck, Camille Dumat, Christophe Laplanche, Antoine Pierart, Mélanie Longchamp, Philippe Besson, Maryse

Castrec-Rouelle

\section{To cite this version:}

Stéphane Mombo, Eva Schreck, Camille Dumat, Christophe Laplanche, Antoine Pierart, et al.. Bioaccessibility of selenium after human ingestion in relation to its chemical species and compartmentalization in maize. Environmental Geochemistry and Health, 2016, 38 (3), pp.869-883. 10.1007/s10653015-9767-z . hal-01346837

\section{HAL Id: hal-01346837 https://hal.science/hal-01346837}

Submitted on 19 Jul 2016

HAL is a multi-disciplinary open access archive for the deposit and dissemination of scientific research documents, whether they are published or not. The documents may come from teaching and research institutions in France or abroad, or from public or private research centers.
L'archive ouverte pluridisciplinaire HAL, est destinée au dépôt et à la diffusion de documents scientifiques de niveau recherche, publiés ou non, émanant des établissements d'enseignement et de recherche français ou étrangers, des laboratoires publics ou privés. 


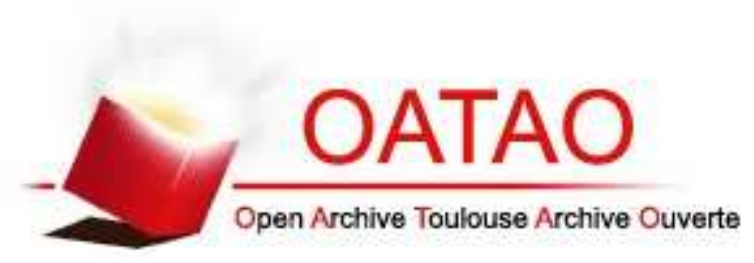

\section{Open Archive TOULOUSE Archive Ouverte (OATAO)}

OATAO is an open access repository that collects the work of Toulouse researchers and makes it freely available over the web where possible.

This is an author-deposited version published in : http://oatao.univ-toulouse.fr/ Eprints ID : 15975

To link to this article : DOI : 10.1007/s10653-015-9767-z URL : http://dx.doi.org/10.1007/s10653-015-9767-z

To cite this version : Mombo, Stéphane and Schreck, Eva and Dumat, Camille and Laplanche, Christophe and Pierart, Antoine and Longchamp, Mélanie and Besson, Philippe and Castrec-Rouelle, Maryse Bioaccessibility of selenium after human ingestion in relation to its chemical species and compartmentalization in maize. (2016) Environmental Geochemistry and Health, vol. 38 (n 3). pp. 869-883. ISSN 0269-4042

Any correspondence concerning this service should be sent to the repository administrator: staff-oatao@ listes-diff.inp-toulouse.fr 


\title{
Bioaccessibility of selenium after human ingestion in relation to its chemical species and compartmentalization in maize
}

\author{
Stéphane Mombo • Eva Schreck • Camille Dumat • Christophe Laplanche • \\ Antoine Pierart • Mélanie Longchamp • Philippe Besson • \\ Maryse Castrec-Rouelle
}

\begin{abstract}
Selenium is a micronutrient needed by all living organisms including humans, but often present in low concentration in food with possible deficiency. From another side, at higher concentrations in soils as observed in seleniferous regions of the world, and in function of its chemical species, Se can also induce (eco)toxicity. Root Se uptake was therefore studied in function of its initial form for maize (Zea mays L.), a plant widely cultivated for human and animal food over the world. Se phytotoxicity and compartmentalization were studied in different aerial plant tissues. For the first time, Se oral human bioaccessibility after ingestion was assessed for the main Se species $\left(\mathrm{Se}^{\mathrm{IV}}\right.$ and $\mathrm{Se}^{\mathrm{VI}}$ ) with the BARGE ex vivo test in maize seeds (consumed by humans), and in stems and leaves
\end{abstract}

\section{S. Mombo · C. Laplanche · A. Pierart}

EcoLab (Laboratoire Ecologie Fonctionnelle et

Environnement), INP, UPS, ENSAT, Université de

Toulouse, Avenue de l'Agrobiopole,

31326 Castanet-Tolosan, France

\section{S. Mombo - C. Laplanche - A. Pierart}

EcoLab, CNRS, 31326 Castanet-Tolosan, France

E. Schreck · P. Besson

Géosciences Environnement Toulouse (GET),

Observatoire Midi Pyrénées, CNRS, IRD, Université de

Toulouse, 14 Avenue E. Belin, 31400 Toulouse, France

\section{Dumat}

CERTOP, UMR5044, Université Toulouse Jean Jaurès, Maison de la Recherche, 5 allée Antonio Machado, 31058 Toulouse Cedex 9, France consumed by animals. Corn seedlings were cultivated in hydroponic conditions supplemented with $1 \mathrm{mg} \mathrm{L}^{-1}$ of selenium ( $\mathrm{Se}^{\mathrm{IV}}, \mathrm{Se}^{\mathrm{VI}}$, Control) for 4 months. Biomass, Se concentration, and bioaccessibility were measured on harvested plants. A reduction in plant biomass was observed under $\mathrm{Se}$ treatments compared to control, suggesting its phytotoxicity. This plant biomass reduction was higher for selenite species than selenate, and seed was the main affected compartment compared to control. Selenium compartmentalization study showed that for selenate species, a preferential accumulation was observed in leaves, whereas selenite translocation was very limited toward maize aerial parts, except in the seeds where selenite concentrations are generally high. Selenium

C. Dumat $(\varangle)$

INP-ENSAT, Av. Agrobiopôle, BP 32607,

31326 Castanet-Tolosan, France

e-mail: camille.dumat@ensat.fr

M. Longchamp

UPMC, UFR 918 - GESE, Sorbonne Universités, 75005 Paris Cedex 05, France

M. Castrec-Rouelle

UPMC, CNRS, EPHE, UMR 7619 Metis, Sorbonne

Universités, 4 Place Jussieu, 75005 Paris, France 
oral bioaccessibility after ingestion fluctuated from 49 to $89 \%$ according to the considered plant tissue and Se species. Whatever the tissue, selenate appeared as the most human bioaccessible form. A potential Se toxicity was highlighted for people living in seleniferous regions, this risk being enhanced by the high Se bioaccessibility.

Keywords Se $\cdot$ Oral bioaccessibility $\cdot$ Health risks · Maize (Zea mays L.) · Chemical species ·

Compartmentalization

\section{Introduction}

Selenium (Se) is first an essential micronutrient for microorganisms, animals, and humans. Actually, several studies have shown the benefits of selenium for human health (Kiremidjian-Schumacher et al. 1994; Rayman 2000; Navarro-Alarcón and LópezMartínez 2000; Kolmogorov et al. 2000; Zhao et al. 2000; Irons et al. 2006). For instance, according to Eckel et al. (2010), Se is reported as a protective factor against cardiovascular diseases or a promoter of good mood for people (Benton and Cook 1990). The World Health Organization (1996) recommended therefore a dietary allowance for human adults between 40 and $200 \mu \mathrm{g}$ Se per day (Zhang et al. 2014). Se mainly enters human food chains through plants consumption (Mayland et al. 1989), such as maize (Zea mays L.), widely cultivated around the world (824 million tons in 2010/2011 according to the Food and Agriculture Organization of the United Nations, FAOSTAT) and largely consumed by humans and animals such as poultry, cattle, and pigs (Le Stum 2011). Mexico has one of the highest consumptions per capita of maize in the world, with a total production of 0.8 million tons in 2011 (FAOSTAT 2004). According to Food and Agriculture Organization data for the year 2005, per capita maize consumptions were 70,104 , and $120 \mathrm{~kg}$ in the USA, South Africa, and Mexico, respectively (FAO 2005). Additionally, this plant can account for nearly $50 \%$ of the humans feed in some countries such as Malawi in Africa (Chilimba et al. 2011). In Asian countries such as China, wheat, rice, and also maize (Zea mays L.) are the main staple grain crops grown (Ma et al. 2008). These crops accounted for $49 \%$ of the total planted area and $86 \%$ of the total grain production in 2004. Mean annual consumptions of rice and wheat flour by rural population in China were, respectively, 248 and $141 \mathrm{~g}$ per person and per day, and the maize consumption is just below (Zhai and Yang 2006). Actually, the production of wheat and maize exponentially grows in China and India (Cui et al. 2010), and their consumption still remains high in Asian regions (Qian et al. 2010). Moreover, maize also has high water requirements and therefore a high impact on the cycling and flux of inorganic elements as selenium within the agricultural system and the food chain (Longchamp et al. 2013).

Selenium is naturally found in soils and its concentration strongly depends on geographical region (Hintze et al. 2001). As shown in Fig. 1 and Table 1, at the global scale, both Se-enriched regions and poor areas can be observed on the earth surface. These Se concentration variations in the soils of the different regions may have direct consequences on $\mathrm{Se}$ absorption by plants. In several countries, Se intake by humans is deficient (i.e., $<40 \mu \mathrm{g}$ Se/person/day) because the soils are naturally poor in this element, and amendments enriched with Se are therefore added to the soils in order to enrich cultures as reported in Finland (Bañuelos et al. 2015; Larsen et al. 2006; Eurola et al. 1990; Carter and Brown 1968). It has been estimated that between 0.5 and 1 billion people globally may have inadequate intakes of Se, and these include populations in developed countries such as western Europe (Combs 2000). However, at the reverse side, in seleniferous regions or areas polluted by anthropogenic Se sources (Qin et al. 2013), high selenium concentrations in soils can induce chronic toxicity linked to Se ingestion throughout food web (Efsa 2008) and then diseases such as Keshan selenosis. Actually, in these areas, high selenium amounts are ingested from 3200 to $6990 \mu \mathrm{g} \mathrm{Se} \mathrm{day}{ }^{-1}$ (Efsa 2008; Qin et al. 2013; Zhang et al. 2014). Thus, research on the health effects due to high dietary intakes of selenium in populations living in seleniferous areas of South Dakota, Venezuela, and China has concluded that the maximum daily intake without any toxicity is $800 \mu \mathrm{g} \mathrm{day}^{-1}$ (Yang and Zhou 1994; Longnecker et al. 1991).

In addition to the total inorganic element concentration in soil, it is well known that the chemical species and compartmentalization can modify the soil-plant transfer, translocation (Ferrand et al. 2006; Shahid et al. 2014; Mombo et al. 2015), and 


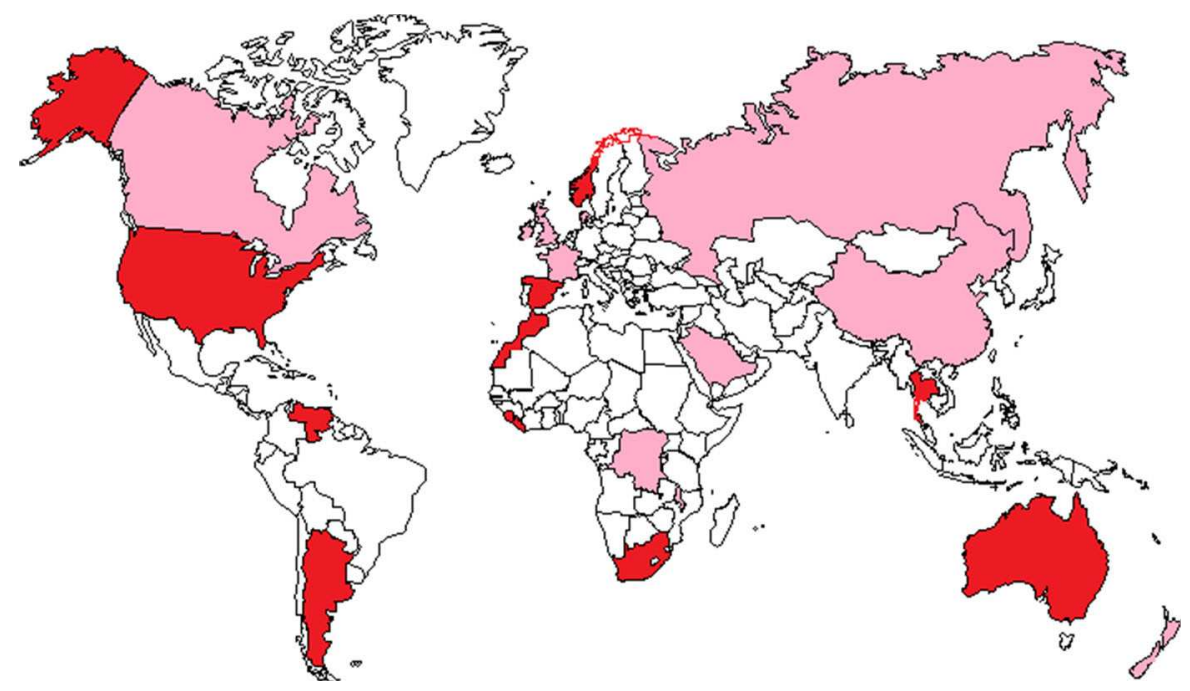

Fig. 1 Selenium distribution at the global scale. World regions naturally enriched in Selenium appear in red (filled square), whereas pink areas correspond to regions with naturally low Se concentration (filled square) and white areas correspond to regions with unknown concentration (opened square). This

spatial distribution figure was built according to the information provided by the World Health Organization (1996) concerning Se contents recorded in various regions worldwide. Areas are qualified of "enriched in Se" when their topsoil Se content exceeds $1.0 \mathrm{mg} \mathrm{kg}^{-1}$ according to Zhang et al. (2014)

Table 1 Variations of Se rates by country

\begin{tabular}{ll}
\hline High rates $(>40 \mu \mathrm{g} \mathrm{Se} /$ person/d) & \\
USA (plains, western Dakota) (Nd) & Hintze et al. (2001), Zhang et al. (2014) \\
China (Hubei) (Nd) & Reilly (1998), Zhang et al. (2014) \\
Japan (Nd) & Lintschinger et al. (2000) \\
Ireland (Nd) & Zhang et al. (2014) \\
Low rates $(<40 \mu \mathrm{g} \mathrm{Se/person/d)}$ & \\
New Zealand (Nd) & Gissel-Nielsen et al. (1984) \\
Burundi $(\mathrm{Nd})$ & Chilimba et al. (2011) \\
Malawi (Nd) & Chilimba et al. (2011) \\
Denmark (Nd) & Nielsen (1968) \\
Russia $(\mathrm{Central}$ and Eastern Siberia) & Combs (2001) \\
Saudi Arabia (15 $\mu \mathrm{g} \mathrm{Se/person/d)}$ & Rayman (2008) \\
Brazil $(33 \mu \mathrm{g} \mathrm{Se/person/d)}$ & Rayman (2008) \\
France (36 $\mu \mathrm{g} \mathrm{Se/person/d)}$ & Lonchamp et al. (2012), Rayman (2008) \\
UK (34 $\mu \mathrm{g} \mathrm{Se/person/d)}$ & Rayman (2000, 2008) \\
Finland (Nd) & Eurola et al. (1990), Koivistoinen (1980), Koivistoinen and Huttunen (1986) \\
China (Nd) & Gissel-Nielsen et al. (1984), Reilly (1998), Li et al. (2007) \\
\hline
\end{tabular}

The criteria of high and low rates of Se were determined to $40 \mu \mathrm{g} \mathrm{Se/person/d} \mathrm{as} \mathrm{defined} \mathrm{by} \mathrm{Zhang} \mathrm{et} \mathrm{al.} \mathrm{(2014)}$

$d$ day, $N d$ unknown concentration

localization in the plant (Austruy et al. 2014; Pierart et al. 2015). Actually, few studies have demonstrated that selenium plant uptake efficiency, allocation, and metabolism in Zea mays are function of Se species ( $\mathrm{Li}$ et al. 2008; Yu et al. 2011; Wang et al. 2012; Longchamp et al. 2013). The naturally occurring in 
soils trace element Se, chemically similar to sulfur (Läuchli 1993), has two inorganic oxidized forms, namely selenite $\left(\mathrm{Se}^{\mathrm{IV}}\right)$ and selenate $\left(\mathrm{Se}^{\mathrm{VI}}\right)$, which are the two main phytoavailable forms in aerobic soils (Avoscan 2007). Several studies concluded that plants accumulate more Se from selenate than selenite (De Souza et al. 1998; Zhang et al. 2003).

According to Ximenez-Embun et al. (2004), after Se plant uptake, biotransformations can occur in the plants: Selenoamino acid is generally produced (about $40 \%$ of the total Se in the plant). These speciation changes in the plants could modify its bioavailability for humans and animals. Actually, organic Se forms are generally more efficiently assimilated by animals and humans than inorganic forms (Rayman 2008). In the context of European Reach regulation (CE $1907 / 2006)$, in vitro tests are promoted in order to limit animal's experimentation. Recently, Xiong et al. (2014a, b) measured metal(loid) bioaccessible fractions in consumed vegetables, using the BARGE ex vivo test procedure (Foucault et al. 2013), in addition to total metal(loid) quantities. Actually, these bioaccessibility measurements are nowadays reported to largely improve the sanitary risk assessment linked to the ingestion of vegetables (Mombo et al. 2015). Total concentrations of pollutants may overestimate the amount absorbed through ingestion (Cave et al. 2006; Denys et al. 2009; Uzu et al. 2011), and thus, the gastric bioavailable fraction of metal(loid)s may be important for global risk evaluation and health impact. The oral bioaccessibility of a metal is operationally defined as the maximum amount of metal solubilized by sequential extraction with synthetic digestive fluids (Oomen et al. 2002) and can be assessed by ex vivo tests. Then, even if only maize seeds are consumed by humans over the world, maize stems and leaves are consumed by animals such as cattle, pigs, and poultry. The assessment of the Se bioaccessible fractions in stems and leaves could give interesting data for their impact on animal health after ingestion and then consequences for terrestrial trophic chains. Even if their digestive system is not really the same as humans, animals can be integrated in a global study of Se uptake and bioaccessibility to better estimate the risks or benefits involved for organisms after consumption.

Finally, the influence of Se chemical species on uptake and compartmentalization in plant tissues has only been little studied, and above all, oral Se bioaccessibility after ingestion according to the considered chemical form has not yet been studied. Thus, this study proposes to explore for the first time the influence of Se chemical species (two main inorganic forms currently observed in the environment were studied: selenite or selenate) on Se human bioaccessibility after ingestion of maize and to link it to its compartmentalization in plant tissues: seeds, stems, and leaves. The experiment was performed for relatively high Se concentrations in nutritive solutions $\left(1 \mathrm{mg} \mathrm{L}^{-1}\right)$ in order to assess the risks involved in Seenriched regions at the global scale. Actually, in these seleniferous regions, Se concentrations in edible parts of plants can reach values between 150 and $950 \mathrm{mg} \mathrm{kg}^{-1}$ in stems and leaves (Eiche et al. 2015). In addition, biomass measurements were taken to determine the potential impact of Se on plant growth and organs development.

Our study finds application for both nutrition and exposure to excessive selenium quantities. Finally, an assessment of health risks (or maybe benefits) due to maize ingestion after Se uptake was proposed by usual sanitary calculations in order to better understand the requirements linked to the population.

\section{Materials and methods}

Experimental setup for maize grown and exposure to the two main inorganic Se chemical forms

Seed germination and maize growth under Se treatments were performed in controlled conditions. First, dried Zea mays subsp. mays (L.) seeds were germinated on glass balls (Longchamp et al. 2013, 2015). Two weeks after germination, Zea mays sups.mays (L.) corn seedlings were grown in hydroponic conditions for 4 months in 20-L plastic tanks filled with a modified Hoagland nutrient solution consisting of $\mathrm{KNO}_{3}(3 \mathrm{mM}), \mathrm{Ca}\left(\mathrm{NO}_{3}\right)_{2} \cdot 4 \mathrm{H}_{2} \mathrm{O}(2.72 \mathrm{mM}), \mathrm{NH}_{4} \mathrm{NO}_{3}$ $(2 \mathrm{mM}), \quad \mathrm{NaCl} \quad(0.2 \mathrm{mM}), \mathrm{KH}_{2} \mathrm{PO}_{4} \quad(0.98 \mathrm{mM})$, $\mathrm{MgSO}_{4} \cdot 7 \mathrm{H}_{2} \mathrm{O} \quad(0.70 \mathrm{mM}), \quad\left(\mathrm{NH}_{4}\right)_{6} \mathrm{Mo}_{7} \mathrm{O}_{24} \cdot 4 \mathrm{H}_{2} \mathrm{O}$ $(0.04 \mu \mathrm{M}), \mathrm{H}_{3} \mathrm{BO}_{3}(24 \mu \mathrm{M}), \mathrm{MnSO}_{4}(13 \mu \mathrm{M}), \mathrm{ZnSO}_{4}$ $(6 \mu \mathrm{M}), \mathrm{CuSO}_{4}(1.5 \mu \mathrm{M})$, and FeEDDHA (6\%) $(4 \mu \mathrm{M})$. Two nutrient solutions were, respectively, supplemented with $12 \mu \mathrm{M}$ selenium (i.e., $1 \mathrm{mg} \mathrm{L}^{-1}$ of selenium) either as two species: $\mathrm{Na}_{2} \mathrm{SeO}_{4}$ or $\mathrm{Na}_{2} \mathrm{SeO}_{3}$ (solutions $\mathrm{Se}^{\mathrm{VI}}-\mathrm{T}$ and $\mathrm{Se}^{\mathrm{IV}}-\mathrm{T}$ ), in order to reach realistic quantities of Se in plant tissues after Se uptake 
and translocation. In the control treatment condition (C-T), no selenium was added. Tanks were placed into a 9- $\mathrm{m}^{3}$ sealed RUBIC5 (Reactor Used for Continental Isotopic Biogeochemistry) plant growth chamber (Servathin, France) as described by Longchamp et al. (2013, 2015). Figure 2 gives an overall picture of the general experimental design with the main measures performed in controlled conditions. Aerial organs (stems, leaves, and seeds) of grown plants were separated and weighted to determine their fresh and dried biomasses (g). Plant samples were then dried and crushed, and then powders were used for both total Se concentrations (see "Total selenium contents in maize tissues" section) and gastric bioaccessibility measurements ("Ex vivo bioaccessibility of Se after plant ingestion by humans" section). Aliquots of the same powder samples were used for Se concentrations on one hand and gastric bioaccessibility measurements

A
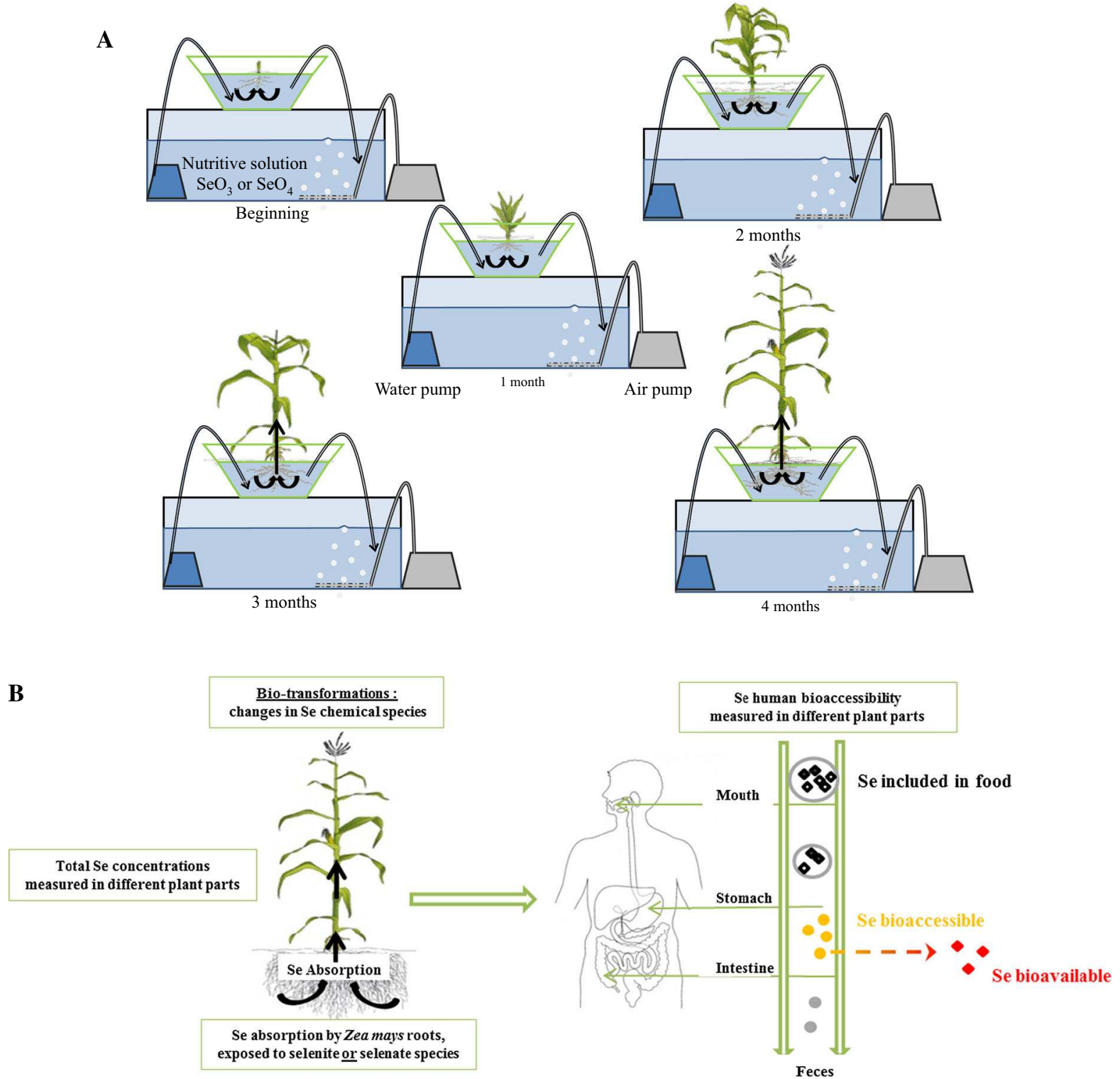

Fig. 2 a Experimental design of plant cultures. b General experimental design with the main measures performed in controlled conditions 
on the other hand. A preliminary analysis (Longchamp et al. 2013) directed the experimental design to five replicates per treatment and the use of a single 20-L plastic tank per treatment.

Total selenium contents in maize tissues

A suitable amount of powdered plant tissue $(125 \mathrm{mg}$ of dry weight DW) was digested in $5 \mathrm{~mL}$ of $\mathrm{HNO}_{3}$ (70\%) and $5 \mathrm{~mL} \mathrm{H}_{2} \mathrm{O}_{2}(30 \%)$ with a Digiprep instrument from SCP Science producer, which is a block digestion system allowing fast and uniform plant sample digestion. Selenium concentrations in the different digested tissues (stems, leaves, and seeds) were obtained by inductively coupled plasma optical emission spectrometry (ICP-OES, Horiba Jobin-Yvon Ultima2), and blank and reference material (White clover, BCR402) were included in each batch of samples. Limit of detection (LOD) for Se in ICP-OES is about $20 \mu \mathrm{g} \mathrm{L}^{-1}$ in solution. LOD for Se in plant tissues is $3.2 \mathrm{mg} \mathrm{kg}^{-1}$ of plant DW. In the C-T plants, the median value of $\mathrm{Se}$ concentrations is about $3.5 \mathrm{mg} \mathrm{kg}^{-1}$ which remains closer to the LOD and very much lower for all Se concentrations in treated plants.

Selenium translocation from roots to shoots was measured by the translocation factor (TF) expressed as the ratio between Se total concentrations in the considered aerial parts $\left(\mathrm{mg} \mathrm{kg}^{-1}\right)$ compared to $\mathrm{Se}$ total concentrations in roots $\left(\mathrm{mg} \mathrm{kg}^{-1}\right)$.

Ex vivo bioaccessibility of Se after plant ingestion by humans

Gastric bioaccessibility (GB) was measured for the different parts of maize plants, using the adapted BARGE unified protocol (Cave et al. 2006; Foucault et al. 2013; Mombo et al. 2015). The BARGE test consists in a three-step extraction procedure to simulate the chemical processes occurring in the mouth, stomach, and intestine compartments using synthetic digestive solutions. The temperature was maintained at $37{ }^{\circ} \mathrm{C}$ throughout the extraction procedure. The chemical composition of each digestive fluid was the same as these previously reported by Denys et al. (2009; Table 2), working on oral bioaccessibility of $\mathrm{Sb}$ investigated with the BARGE protocol. The extraction test procedure was also previously described by Wragg et al. (2011). Dried and sieved
Table 2 Translocation factors (TF) calculated for leaves, stems, and seeds for each Se species exposure

\begin{tabular}{lll}
\hline & $\begin{array}{l}\text { Selenate exposure } \\
\left(1 \mathrm{~m} \mathrm{~L} \mathrm{~L}^{-1}\right)\end{array}$ & $\begin{array}{l}\text { Selenite exposure } \\
\left(1 \mathrm{mg} \mathrm{L}^{-1}\right)\end{array}$ \\
\hline TF for seeds & 0.85 & 0.19 \\
TF for leaves & 2.49 & 0.09 \\
TF for stems & 1.08 & 0.13 \\
\hline
\end{tabular}

vegetable samples $(0.6 \mathrm{~g})$ were mixed with $9 \mathrm{~mL}$ of saliva (pH 6.5) and shaken for $5 \mathrm{~min}$. Then $13.5 \mathrm{~mL}$ of gastric solution ( $\mathrm{pH}$ 1.0) was added to the suspension. The $\mathrm{pH}$ of the solution was reduced to 1.2 using $\mathrm{HCl}$ if necessary. The suspension was mixed using an endover-end rotation agitator at $37{ }^{\circ} \mathrm{C}$ for $1 \mathrm{~h}$. The $\mathrm{pH}$ of the suspension was checked to be in the range of 1.21.6. The stomach phase was extracted by centrifuging the suspension at $3000 \times g$ for $5 \mathrm{~min}$ with Heraeus Megafuge 1.0 R apparatus (Wragg et al. 2011). Se concentrations in the gastric phase solution were measured by ICP-OES, and results are expressed in milligrams of bioaccessible Se per $\mathrm{kg}$ of solid matrix (vegetable). The percentage of bioaccessible Se was compared with the total Se concentrations measured in the edible plant parts. Bioaccessibility results were expressed as the percentage of the initial total $\mathrm{Se}$ content in plant tissue dissolved during the bioaccessibility assay, as expressed in Eq. (1):

$$
\begin{aligned}
& \text { Gastric Bioaccessibility of Se }(\%) \\
& =\left(\text { Bioaccessible Se concentration }\left(\mathrm{mg} \mathrm{kg}^{-1}\right) /\right. \\
& \left.\quad \text { Total Se concentration }\left(\mathrm{mg} \mathrm{kg}^{-1}\right)\right) \times 100
\end{aligned}
$$

\section{Statistical analyses}

The significance of differences of tissue dry weights, Se concentrations, and Se bioaccessible fractions between treatments (Control, $\mathrm{Se}^{\mathrm{VI}}-\mathrm{T}$, or $\mathrm{Se}^{\mathrm{IV}}-\mathrm{T}$ ) and between plants compartments (stems, leaves, or seeds) were evaluated by performing analyses of variances (ANOVAs). Prospective differences in treatment effects between plant compartments are investigated via the "treatment: compartment" interaction term. An additional factor — "plant" — was considered in the analysis in order to account for stem, leaf, and seed material originating from same plants and detect prospective differences of dry weights, Se concentrations, and Se bioaccessible fractions between plants. 
As a summary, three 3-way ANOVA were performed (factors: treatment, compartment, treatment:compartment, and plant; dependent variables: dry weight, Se concentration, and Se bioaccessible fraction). Normality and homoscedasticity of ANOVA residuals were checked with Shapiro-Wilk (SW) and Brown-Forsythe (BF) tests. Significance of pairwise differences was determined using Fisher's least significant difference (LSD) test with a type I error of $5 \%$. Group mean and within-group variability are expressed as mean \pm standard error of the mean (SEM). Statistical analyses were performed with $\mathrm{R}$ version 3.1.2 (Killick et al. 2014).

\section{Results and discussion}

Differences of plant biomass, Se total concentration, and bioaccessible fraction between treatments and compartments are illustrated in Figs. 3, 4, and 5, respectively. Results ( $p$ values) of the ANOVAs are summarized in figure captions (Fig. 3, 4, 5). Results of LSD tests are superimposed to the plots. Results show (with the exception of "plant" and "treatment: compartment" factors with respect to the bioaccessible fraction) significant differences of biomass, total concentration, and bioaccessible fraction across treatments, compartments, and plants. Results are presented in more detail and discussed below.

Plant tissue biomasses and Se phytotoxicity assessment

Results show that significant growth retardation occurs on aerial parts of plants exposed to Se at a concentration of $1 \mathrm{mg} \mathrm{L}^{-1}$, for both $\mathrm{Se}^{\mathrm{VI}}-\mathrm{T}$ and $\mathrm{Se}^{\mathrm{IV}}-\mathrm{T}$ (Fig. 3). A significant decrease in dry weight of the maize seeds and stems exposed to Se was observed, compared to the controls. The loss of weight was higher in our study for selenite species than selenate, suggesting a higher impact of the $\mathrm{Se}^{\mathrm{IV}}$ form on phytotoxicity, as already observed by Ximenez-Emun et al. (2004). As suggested by Fig. 3, the main organ affected by phytotoxicity symptoms is the seed with the most significant decrease in tissue biomass. Previous studies, done in the same experimental context but with maize plants exposed to low Se concentrations (between 10 and $50 \mu \mathrm{g} \mathrm{L}^{-1}$, as reported in Hubei region), have shown that whatever the chemical form applied (selenite or selenate), no significant change was observed in shoot biomasses (Longchamp et al. 2013). Then, for low Se concentrations, phytotoxicity did not occur.

Working on perennial ryegrass and strawberry clover, Hopper and Parker (1999) already reported that selenite was more phytotoxic than selenate, especially for shoot growth. They underlined that selenate preferentially inhibits root growth and had less effects on aerial parts. Moreover, Lonso et al. (2004) working on indian mustard (Brassica juncea), sunflower (Helianthus annus), and white lupine (Lupinus albus) growing on $1 \mathrm{mg} \mathrm{L}^{-1}$ of $\mathrm{Se}$ as $\mathrm{Na}_{2} \mathrm{SeO}_{4}$ showed an accumulation of $\mathrm{Se}$ in plant leaves and a decrease in plant biomass.

Total Se concentrations measured in maize compartments

The values of selenium concentrations in the different plant aerial parts (Fig. 4) are in accordance with the measured values obtained in plants grown in seleniferous regions. For example, Eiche et al. (2015) working on Se distribution of plant biomass wheat (Triticum aestivum) and Indian mustard (Brassica juncea) from a seleniferous area of Punjab, India, reported that Se concentrations reached, respectively, 387 and $191 \mathrm{mg} \mathrm{kg}^{-1}$ of DW in wheat leaves and stems, and, respectively, 931 and $133 \mathrm{mg} \mathrm{kg}^{-1}$ of DW in mustard leaves and stems. By contrast, for control plants, no significant variations were observed and Se accumulation is very low whatever the considered plant tissue.

Selenium concentrations measured in maize strongly depend of the considered plant tissue: Actually, a significant compartmentalization appears in our results (Fig. 4). For selenate species, a preferential accumulation was observed in leaves $\left(219 \mathrm{mg} \mathrm{kg}^{-1}\right)$, in comparison with stems $\left(95 \mathrm{mg} \mathrm{kg}^{-1}\right)$ and seeds $\left(74 \mathrm{mg} \mathrm{kg}^{-1}\right)$. This accumulation in leaves after selenate form uptake from roots was already observed by several authors on different plants: They noticed that selenate accumulation was three to four times higher in the leaves compared to selenite, particularly for broccoli, sugar beets, white lupine, and sunflowers (De Souza et al. 1998; Ximenez-Embun et al. 2004; Zayed et al. 1998). Similarly, Zayed et al. (1998) or Li et al. (2008) found a high selenate accumulation in rice and wheat leaves. 


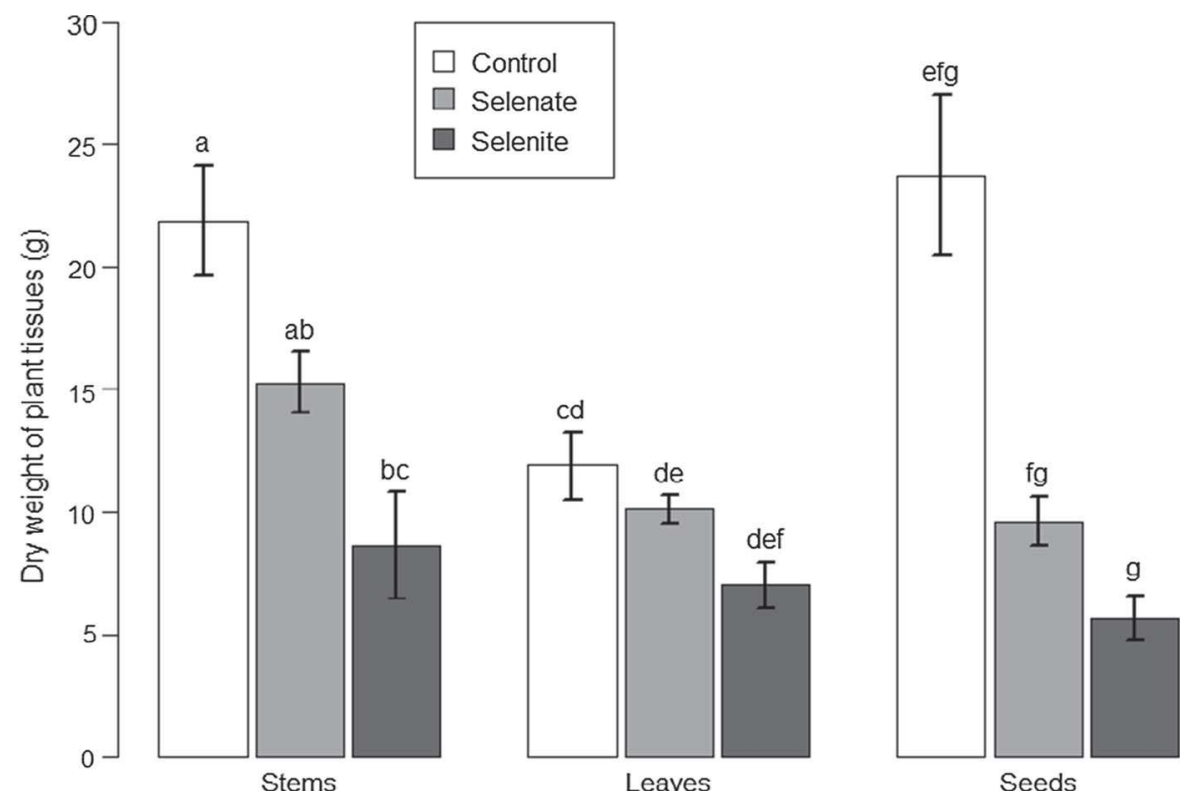

Fig. 3 Plant biomass (g DW) measured in different aerial maize compartments (stems, leaves, and seeds) for two species: selenite and selenate added in the hydroponic solution at $1 \mathrm{mg} \mathrm{L}^{-1}$ and controls, three conditions and five plants for each condition. Results are illustrated as the mean $\pm \operatorname{SEM}(n=5)$. ANOVA (SW: 0.615; BF: 0.466; biomass was log-transformed to satisfy ANOVA assumptions) shows significant differences

For selenite species, the concentrations observed in the different aerial plant tissues differ; however, the seeds appear as the most concentrated organ in Se ( $p$ value $<0.05$ ). This high accumulation of selenite in maize seeds could be linked to its phytotoxicity observed in terms of aerial parts biomasses: Actually, a higher decrease in dry weight of the maize seeds was observed for selenite species than selenate, suggesting a higher phytotoxic impact of the $\mathrm{Se}^{\mathrm{IV}}$ form, as already observed by Ximenez-Emun et al. (2004). Concerning the stems, no significant differences were observed according to the Se species considered.

Concerning the speciation of the different accumulated forms, Asher et al. (1977) analyzed Se concentrations and chemical forms in the sap of tomato (Lycopersicon esculentum) treated with selenate or selenite, as well as in our experiment. They reported that selenate was entirely transported unchanged, while very little selenite could be detected in the xylem of treated plants.

We hypothesize that the differences of Se concentrations in plant tissues could be induced by their chemical species in the nutritive solution, and maybe of biomass across treatments $(p=5.399 \mathrm{e}-14 * * *)$, compartments $(p=3.399 \mathrm{e}-06 * * *)$, plants $(p=5.942 \mathrm{e}-07 * * *)$, and a significant treatment: compartment interaction $(p=2.847 \mathrm{e}-$ $05 * * *)$. Levels of significance are as follows: $* * *(p<0.001)$, $* *(p<0.01)$, and $*(p<0.05)$. Different letters indicate significant pairwise differences across treatments and plant compartments (LSD; $p<0.05$ )

explained by the concentrations of the various chemical elements that enter in the constitution of the nutrient solution. Indeed, Li et al. (2008) explain that such a difference in Se concentrations according to the tissues and the considered species is mainly due to phosphate in the nutrient solution: Phosphate inhibits the absorption of selenite, thus promoting the uptake of selenate. The presence of $\mathrm{KH}_{2} \mathrm{PO}_{4}(0.98 \mathrm{mM})$ in the Hoagland nutrient solution of this study can explain the higher concentrations of Se accumulated in maize leaves and stems after selenate exposure. Also, structural similarity between the selenate form $\mathrm{Se}^{\mathrm{VI}}$ and the sulfate ion $\left(\mathrm{SO}_{4}^{-2}\right)$ allows the selenate to pass through the sulfates channels by different pathways, being then transported without modifying its chemical structure through the xylem to the leaves, which allows finding it in large quantities in the different compartments of the plant, and especially in the leaves. This hypothesis is directly in accordance with our findings highlighting a higher accumulation of Se in the leaves of the plants exposed to selenate than those exposed to selenite. Moreover, sulfate ions are involved in plant transpiration (Marschner 1995) 




Fig. 4 Se total concentrations $\left(\mu \mathrm{g} \mathrm{g}^{-1} \mathrm{DW}\right)$ measured in different aerial maize compartments (stems, leaves, and seeds) for two species: selenite and selenate added in the hydroponic solution at $1 \mathrm{mg} \mathrm{L}^{-1}$ and controls. ANOVA (SW: 0.6719; BF: 0.1481; controls were excluded to satisfy ANOVA assumptions) shows significant differences of Se concentration across

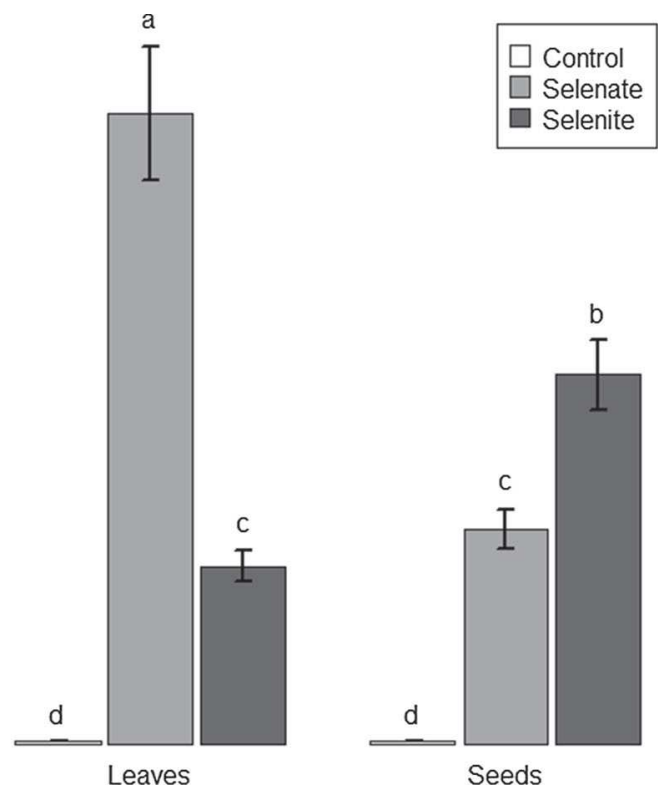

treatments $(p=4.948 \mathrm{e}-4 * * *)$, compartments $(p=5.515 \mathrm{e}-$ $4 * * *)$, plants $\left(p=0.0403^{*}\right)$, and a significant treatment: compartment interaction $\left(p=1.163 \mathrm{e}-07^{* * *}\right)$. See legend of Fig. 3 for the interpretation of confidence intervals, significance levels, and grouping letters

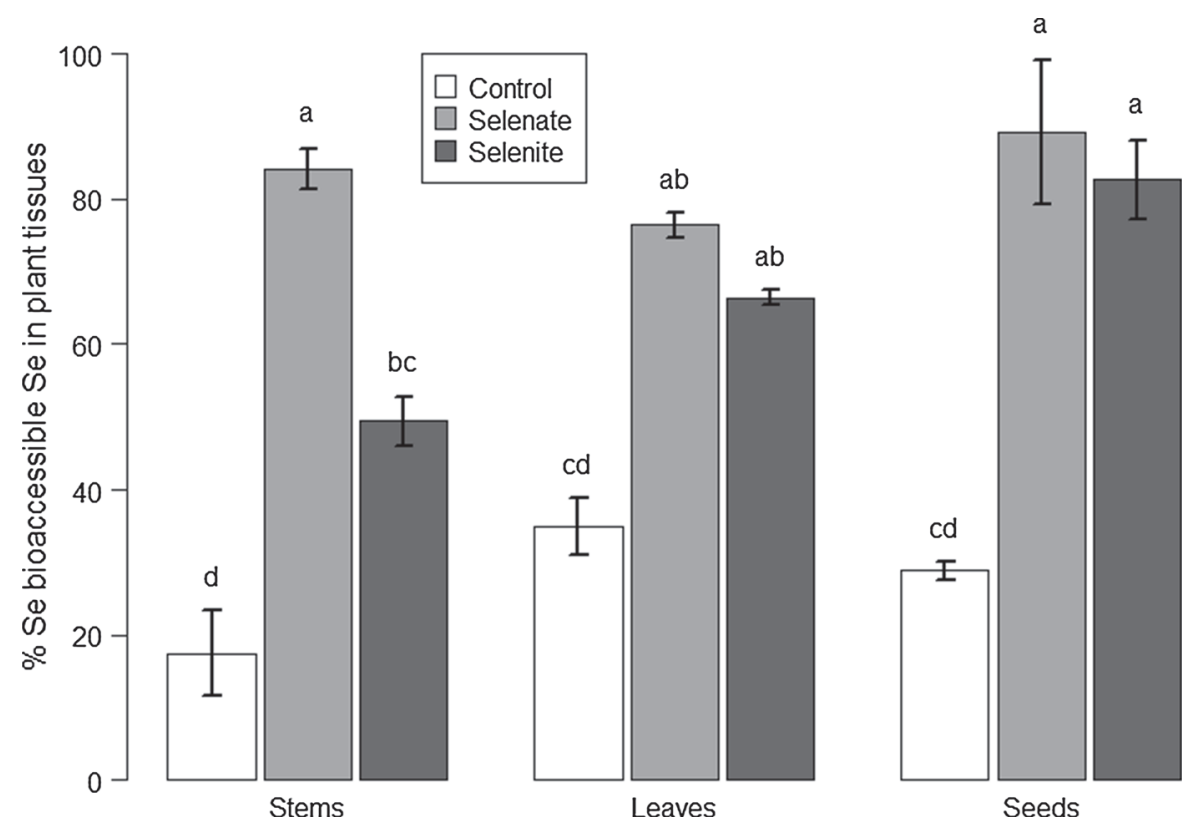

Fig. 5 Se bioaccessible fractions estimated in different maize compartments (stems, leaves, and seeds) for two species of complemented Se: selenite and selenate added in the hydroponic solution at $1 \mathrm{mg} \mathrm{L}^{-1}$ and control. ANOVA (SW: 0.666; BF: 0.207 ) shows significant differences of bioaccessible fraction

across treatments $(p=1.715 \mathrm{e}-10 * * *)$ and compartments $\left(p=0.007375^{* *}\right)$ without differences between plants ( $p=0.904)$ and without treatment: compartment interaction $(p=0.0701)$. See legend of Fig. 3 for the interpretation of confidence intervals, significance levels, and grouping letters 
which could explain the high concentration in the leaves of the plant exposed to selenate species. Lintschinger et al. (2000) found that for sunflower plants grown in a solution concentrated in selenate, no chemical species change was observed in the xylem, suggesting an accumulation of $\mathrm{Se}^{\mathrm{VI}}$ form in aerial parts. Finally, according to (Ximenez-Emun et al. 2004), selenite is more easily metabolisable. An increase in the number of chemical species was observed in the different compartments of the plants that were grown in the selenite, while metabolism of selenate is much slower. Then, considering all these statements, a significant compartmentalization seems to appear in the exposed plants, depending on the $\mathrm{Se}$ chemical form of exposure.

Translocation factor (TF) was calculated as expressed in the "Total selenium contents in maize tissues" section, and results are given in Table 2. This factor gives relevant information on the compartmentalization process due to the species form in nutritive solution.

Total Se concentrations in roots were particularly high in case of selenite exposure (it raised $686 \pm 15 \mathrm{mg} \mathrm{kg}^{-1}$; results not shown). It was approximatively ten times superior compared to selenate exposure $\left(88 \pm 2 \mathrm{mg} \mathrm{kg}^{-1}\right)$. In our study, the high translocation factor of selenate (especially in the leaves: $\mathrm{TF}=2.49$ for selenate exposure) is not only explained by its low concentration in roots but also by its high accumulation in leaf organ. Similarly, it has been shown that Indian mustard grown in soils enriched with selenate accumulates more Se in their shoots than plants grown on selenite-enriched soils (Banuelos et al. 1995). Working on perennial ryegrass and strawberry clover, Hopper and Parker (1999) have also already reported that translocation percentages were much higher with selenate $(\geq 84 \%)$ than with selenite $(\leq 47 \%)$. This observation was also made by De Souza et al. (1998) for Indian mustard: They reported that selenate was rapidly translocated to the shoot, away from the root, the site of volatilization into dimethyl selenide, whereas only approximately $10 \%$ of the selenite was translocated. Our observations are thus in line with the results of various previous studies, which have shown that selenite is mainly retained within the roots and quickly transformed to organic forms like SeCys or SeMet (De Souza et al. 1998; Zayed et al. 1998; Li et al. 2008; Kikkert and Berkelaar 2013; Wang et al. 2013; Eiche et al.
2015). According to Li et al. (2008) and Kikkert and Berkelaar (2013), only a small fraction $(<12 \%)$ of selenite migrates to the aerial parts. Selenium species by X-ray absorption spectroscopy revealed that selenite-supplied plants accumulated organic Se, most likely selenomethionine, whereas selenate-supplied plants accumulated selenate (De Souza et al. 1998).

\section{Selenium gastric bioaccessibility (GB) in maize}

Selenium bioaccessibility (Fig. 5) values ranged from 17.5 to $35 \%$ in control plants in mean of five samples, according to the considered compartment, with a trend of higher bioaccessibility of Se in maize leaves. As explained in "Statistical analyses" section, we included the "plant" factor in the ANOVAs in order to account for the grouping structure of stem, leaf, and seed data samples originating from the same plants in view of detecting differences of dry weights, Se concentrations, and Se bioaccessible fractions between plants. Results show that the bioaccessible fraction is not plant dependent ( $p=0.904$; Fig. 5), highlighting the interest of using this fraction to overcome the biological material chosen. Concerning supplemented Se in hydroponic solutions, results showed that bioaccessibility percents fluctuate between 49 and $89 \%$ according to the considered plant tissue and the chemical form of Se applied in the nutrient solution. Actually, even if biotransformations and species changes can occur in the plant system (Ximenez-Embun et al. 2004), the chemical form of Se of which plants are exposed can induce variations in Se oral bioaccessibility according to the plant edible parts. Similar results concerning Se bioaccessibility were observed in the case of fishes consumption by Cabañero et al. (2004) working on fishes enriches with Se consumed by people (Se bioaccessibility between 42 and $83 \%$ ) and Bhatia et al. (2013) working on Pleurotus mushrooms. Cabañero et al. (2004) reported that selenium bioaccessibility varied depending on the type of fish analyzed, suggesting a role of the involved accumulation tissues and biotransformation throughout the living organisms.

Whatever the tissue, selenate appears as the most bioaccessible form for humans, with significant higher values reported for stems and leaves. Selenate is the highly bioavailable form of soluble Se that is most commonly found in soils and subsurface drainage waters (Terry and Banuelos 2012). The same trend is 
observed for seeds, usually consumed by human organisms, but results are here not significant. By contrast, working on Se oral bioaccessibility in leek (Allium ampeloprasum), Lavu et al. (2012) highlighted that in the gastric phase, Se bioaccessibility was slightly higher when the leek was grown on selenite-enriched soil (63\%), as compared to selenate-enriched soil (56\%), although this difference is not significant. In our study, there is no significant difference in selenate bioaccessible fraction in function of the maize tissue, i.e., stems, leaves, or seeds. However, selenate human bioaccessibility after ingestion follows the sequence: seeds $>$ stems $>$ leaves, suggesting a potential impact on human health due to seeds consumption.

Microbiota living in human intestine can be responsible of these chemical form changes and can direct metal uptake according to the species and then influence bioaccessibility values and fluctuations. Actually, working on Se bioaccessibility in the human intestine, Lavu et al. (2013) reported that Se bioaccessibility decreases to below 40 and $70 \%$ after $48 \mathrm{~h}$ of colon incubation for SeMet and selenate, respectively. This phenomenon was attributed to bacteria cell fractions of gut contents and feces that uptake actively $\mathrm{Se}$ as a micronutrient for their metabolic processes. The different decrease in percentages is explained by the preferential species of Se uptaken by microbiota in human guts: Selenate is not the preferred form, compared to SeMet.

Human exposure to Se and assessment of health benefits or risks

In order to assess the impact of Se on human health after ingestion of exposed maize via root transfer, daily intake (DI, $\mu \mathrm{g} \mathrm{day}^{-1}$ ) can be estimated from the measured Se concentrations in plant seeds $\left(\mu \mathrm{g} \mathrm{kg}^{-1}\right)$ for high Se-enriched regions in the world and daily maize consumption rates $\left(\mathrm{kg} \mathrm{day}^{-1}\right)$, for highly exposed people too.

The average daily consumption of maize seeds per person (body weight of an average adult: $65 \mathrm{~kg}$ ) can be variable according to the considered country around the world. But, in Africa, the mean daily intake of maize is about $102 \mathrm{~g}$ per capita per day (as a mean of 45 countries) as reported by Nuss and Tanumihardjo (2011). Mekonen et al. (2015) reported a daily value of approximately $6 \mathrm{~g}$ of maize consumed per $\mathrm{kg}$ of body weight and per day in Ethiopia, Africa. In Mexico, those values reach the level of $315 \mathrm{~g}$ per capita per day (CNMI 2001; Rosas-Castor et al. 2014).

The following equation (Eq. 2) is generally used to calculate the daily intake of metal (Cui et al. 2004; Sharma et al. 2009; Swartjes 2011; Okorie et al. 2012):

$$
\begin{aligned}
& \text { Daily intake of metal }\left(\mathrm{DI}, \mu \mathrm{g} \mathrm{d}^{-1}\right) \\
& =\text { vegetable metal concentration }\left(\mathrm{mg} \mathrm{kg}^{-1} \text { of } \mathrm{FW}\right) \\
& \times \text { daily vegetable consumption }(\mathrm{g} \text { per day }) / \\
& \quad \text { body weight }(\mathrm{kg} ; 65 \mathrm{~kg} \text { for an average adult })
\end{aligned}
$$

In our study, the average measured concentrations in maize seeds due to root uptake of Se was 76.2 and $128.4 \mathrm{mg} \mathrm{kg}^{-1}$ of DW for, respectively, selenate and selenite. Vegetable metal concentrations of DW were then converted into concentrations of fresh weight (FW) by multiplying by the percent of dry matter in the sampled seed, averaged at $67 \%$ for our maize seeds. The determined DI values are then compared to tolerable daily intake (TDI, $\mu \mathrm{g} \mathrm{kg}^{-1} \mathrm{day}^{-1}$ ) expressed as the quantity of metal ingested each day $(\mu \mathrm{g})$ as a function of $\mathrm{kg}$ body weight. This TDI was established by the Food Safety Commission of Japan at $4 \mu \mathrm{g} \mathrm{kg}^{-1} \mathrm{day}^{-1}$ for Se (FSCJ 2012), as an essential element.

The maximum daily quantities of vegetables consumed from high exposed areas to reach the TDI can therefore be calculated using Eq. 3:

$$
\begin{aligned}
& \text { Daily vegetable consumption } \\
& \text { (kg plant per kg body weight and per day) } \\
& =\mathrm{TDI}\left(\mu \mathrm{g} \mathrm{kg}^{-1} \mathrm{~d}^{-1}\right) / \\
& \quad \text { vegetable metal concentration }\left(\mu \mathrm{g} \mathrm{kg}^{-1}\right)
\end{aligned}
$$

The maximum daily quantity of vegetables exposed to Se that can be consumed without exceeding the TDI was therefore calculated using the concentration values measured for the exposed maize seeds and $65 \mathrm{~kg}$ for the body weight of an average adult. These values are given in Table 3 for the two different Se species. The results showed a risk for very low quantities of maize seeds consumed, suggesting a toxic exposure of people living in the seleniferous regions taken as examples. Actually, the maximum daily quantity of vegetable that can be consumed by an adult of $65 \mathrm{~kg}$ is, respectively, 5.1 and $3.0 \mathrm{~g} \mathrm{day}^{-1}$ of maize seeds exposed to selenate and selenite 
Table 3 Calculated maximum daily quantities of maize seeds $\left(\mathrm{g} \mathrm{day}^{-1}\right.$ ) exposed to Se in seleniferous regions that can be consumed without exceeding the TDI

\begin{tabular}{lllll}
\hline Se speciation exposure & $\begin{array}{l}\text { Daily intake } \\
\text { of Se (DI, } \\
\left.\mu \mathrm{g} \mathrm{day}{ }^{-1}\right)\end{array}$ & $\begin{array}{l}\text { Tolerable daily } \\
\text { intake (TDI, } \\
\left.\mu \mathrm{gg}^{-1} \mathrm{day}^{-1}\right)\end{array}$ & $\begin{array}{l}\text { Maximum daily quantity } \\
\text { of maize seeds exposed } \\
\text { to Se for an adult } \\
\text { of } 65 \mathrm{~kg}\left(\mathrm{~g} \mathrm{day}^{-1}\right)\end{array}$ & $\begin{array}{l}\text { Conclusions: risks } \\
\text { for human health? }\end{array}$ \\
\hline $\begin{array}{l}\text { Selenate }\left(1 \mathrm{mg} \mathrm{L}^{-1}\right) \\
\text { Selenite }\left(1 \mathrm{mg} \mathrm{L}^{-1}\right)\end{array}$ & 247.5 & 4 & 5.1 & $\begin{array}{l}\text { Risks involved for people living } \\
\text { in seleniferous areas }\end{array}$ \\
\hline
\end{tabular}

(Table 3). Moreover, due to the high GB of Se in maize, there is finally a low decrease in the Se DI if the bioaccessible fraction is taken into consideration instead of total Se concentrations. Finally, the root Se transfer can therefore lead to significant health risks when high Se amounts are measured in soils and irrigation waters in seleniferous regions.

\section{Conclusions and perspectives}

Focusing on an experiment performed on maize crops grown on hydroponic solutions supplemented in Se with two different chemical forms $\left(\mathrm{Se}^{\mathrm{IV}}\right.$ and $\left.\mathrm{Se}^{\mathrm{VI}}\right)$, this study reported the bioaccessibility of selenium after human ingestion in relation to its compartmentalization in maize. Selenium compartmentalization in plant tissues depends on its chemical species uptaken by the maize plants. Selenium accumulated concentrations in maize vary according to the considered plant tissue and its chemical species in the nutritive solution.

For the first time, Se oral human bioaccessibility after ingestion was assessed for these two different Se species forms with the BARGE ex vivo test in maize crops. Selenium oral bioaccessibility after ingestion showed high values from 49 to $89 \%$ according to the considered plant tissue and the chemical form. Whatever the tissue, selenate appears as the most bioaccessible form for humans, with significant high values reported for stems and leaves. Moreover, the maximum daily quantity of maize seeds exposed to Se that can be consumed without exceeding the tolerable daily intake had highlighted a toxic exposure of people living in widely exposed areas, especially as Se is highly gastric bioaccessible in maize seeds. Then, Se oral bioaccessibility is highly linked to its chemical species and compartmentalization in consumed maize. Our study has therefore consequences for the assessment of Se absorption by humans with both toxicity and alimentation considerations. Actually, plant quality is a crucial subject for human health and participative socio-scientific projects such as "RéseauAgriville" are developed to widely educate citizens about the various parameters that influence the quality of the consumed cultivated plants.

Acknowledgments This work has received support from Gabon through A.N.B.G for the Ph.D. of Mombo S. Biron P and Bariac T. from iEES-UPMC are thanked for RUBIC5 access. This work has received financial supports from National Research Agency under reference ANR-12-0011-VBDU and the National Polytechnic Institute in Toulouse (INPT). The authors thank to Leigh Gebbie for English review.

\section{References}

Asher, C. J., Butler, G. W., \& Peterson, P. J. (1977). Selenium transport in root systems of tomato. Journal of Experimental Botany, 28(103), 279-291.

Austruy, A., Shahid, M., Xiong, T., Castrec, M., Payre, V., Niazi, N. K., \& Dumat, C. (2014). Mechanisms of metalphosphates formation in the rhizosphere soils of pea and tomato: Environmental and sanitary consequences. Journal of Soils and Sediments, 14, 666-678.

Avoscan, L. (2007). Etude de la résistance de Cupriavidus metallidurans $\mathrm{CH} 34$ aux oxyanions sélénite et séléniate: Accumulation, localisation et transformation du sélénium. Thèse de doctorat d'université. Joseph Fourier: Université Grenoble 1, 244 p.

Bañuelos, G. S., Arroyo, I., Pickering, I. J., In, S., \& Freeman, J. L. (2015). Selenium biofortification of broccoli and carrots grown in soil amended with Se-enriched hyperaccumulator Stanleya pinnata. Food Chemistry, 166, 603-608.

Banuelos, G. S., Terry, N., Zayed, A., \& Wu, L. (1995). Managing high soil Se with phytoremediation. In G. E. Schuman \& G. F. Vance (Eds.), Selenium, mining, reclamation, and environmental impact. Proceedings of the 12th Annual Meeting of the American Society for Surface Mining and Reclamation. American Society for Surface Mining and Reclamation, pp. 394-405.

Benton, D., \& Cook, R. (1990). Selenium supplementation improves mood in a double-blind crossover trial. Psychopharmacology, 102(4), 549-550.

Bhatia, P., Aureli, F., D’Amato, M., Prakash, R., Cameotra, S. S., Nagaraja, T. P., \& Cubadda, F. (2013). Selenium bioaccessibility and speciation in biofortified Pleurotus 
mushrooms grown on selenium-rich agricultural residues. Food Chemistry, 140(1-2), 225-230.

Cabañero, A. I., Madrid, Y., \& Cámara, C. (2004). Selenium and mercury bioaccessibility in fish samples: An in vitro digestion method. Analytica Chimica Acta, 526(1), 51-61.

Carter, D. L., \& Brown, M. J. (1968). Selenium concentrations in forage on some high northwestern range. Journal of Range Management, 23, 234-238.

Cave, M., Wragg, J., Klinck, B., Grön, C., Oomen, T., Van de Wiele, T., et al. (2006). Preliminary assessment of a unified bioaccessibility method for Arsenic in soils. International conference in Epidemiology and Environmental Exposure. Paris, 2-6 September 2006.

Chilimba, A. D. C., Young, S. D., Black, C. R., Rogerson, K. B., Ander, E. L., Watts, M. J., et al. (2011). Maize grain and soil surveys reveal suboptimal dietary selenium intake is widespread in Malawi. Scientific Reports, 72, 1-9.

CNMI (Cámara Nacional del Maíz Industrializado). (2001). Retrieved 16 de octubre, 2012, from http://www.cnmaiz. org.mx/camara.html.

Combs, G. F. (2000). Food system-based approaches to improving micronutrient nutrition: The case for selenium. Biofactors, 12, 39-43.

Combs, G. F. (2001). Selenium in global food systems. British Journal of Nutrition, 85, 517-547.

Cui, Z., Chen, X., \& Zhang, F. (2010). Current nitrogen management status and measures to improve the intensive wheat-maize system in China. Ambio, 39(6), 376-384.

Cui, Y. J., Zhu, Y. G., Zhai, R. H., Chen, D. Y., Huang, Y. Z., Qiu, Y., et al. (2004). Transfer of metals from soil to vegetables in an area near a smelter in Nanning, China. Environment International, 30(6), 785-791.

De Souza, M. P., Pilon-Smits, E. A. H., Lytle, C. M., Hwang, S., Tai, J., Honma, T. S. U., et al. (1998). Rate-limiting steps in selenium assimilation and volatilization by Indian Mustard. Plant Physiology, 117, 1487-1494.

Denys, S., Tack, K., Caboche, J., \& Delalain, P. (2009). Bioaccessibility, solid phase distribution, and speciation of $\mathrm{Sb}$ in soils and in digestive fluids. Chemosphere, 74(5), 711-716.

Eckel, R. H., Alberti, K. G. M. M., Grundy, S. M., \& Zimmet, P. Z. (2010). The metabolic syndrome. Lancet, 375(9710), $181-183$.

Efsa, Q. (2008). La levure enrichie en sélénium ajoutée à des fins nutritionnelles en tant que source de sélénium à des aliments destinés à des usages nutritionnels particuliers et à des aliments (y compris des compléments alimentaires) destinés à la population générale.

Eiche, E., Bardelli, F., Nothstein, A. K., Charlet, L., Göttlicher, J., Steininger, R., et al. (2015). Selenium distribution and speciation in plant parts of wheat (Triticum aestivum) and Indian mustard (Brassica juncea) from a seleniferous area of Punjab, India. Science of the Total Environment, 505, 952-961.

Eurola, M., Ekholm, P., Ylinen, M., Koivistoinen, P., \& Varo, P. (1990). Effects of selenium fertilization on the selenium content of cereal grains, flour and bread produced in Finland. Cereal Chemistry, 67, 2-5

FAO. (2005). Food and Agriculture Organization of United Nations. Retrieved 23 March, 2012, from www.fao.org/ home/en/.
FAOSTAT. (2004). Food and Agriculture Organization of the United Nations. Retrieved 13 de mayo http://faostat.fao. org/site/613/DesktopDefault.aspx?PageID=613\#ancor.

Ferrand, E., Dumat, C., Leclerc-Cessac, E., \& Benedetti, M. F. (2006). Phytoavailability of zirconium in relation to its initial added form and soil characteristics. Plant and Soil, 287(1-2), 313-325.

Foucault, Y., Lévêque, T., Xiong, T., Schreck, E., Austruy, A., Shahid, M., et al. (2013). Green manure plants for remediation of soils polluted by metals and metalloids: Ecotoxicity and human bioavailability assessment. Chemosphere, 93(7), 1430-1435.

FSCJ: Food Safety Commission of Japan. (2012). Risk assessment report—chemicals and contaminants FS/946/2012.

Gissel-Nielsen, G., Gupta, U. C., Lamand, M., \& Westermarck, T. (1984). Selenium in soils and plants and its importance in livestock and human nutrition. Advances in Agronomy, 37, 397-460.

Hintze, K. J., Lardy, G. P., Marchello, M. J., \& Finley, J. W. (2001). Areas with high concentrations of selenium in the soil and forage produce beef with enhanced concentrations of selenium. Journal of Agricultural and Food Chemistry, 49(2), 1062-1067.

Hopper, J. L., \& Parker, D. R. (1999). Plant availability of selenite and selenate as influenced by the competing ions phosphate and sulfate. Plant and Soil, 1937, 199-207.

Irons, R., Carlson, B. A., Hatfield, D. L., \& Davis, C. D. (2006). Both selenoproteins and low molecular weight selenocompounds reduce colon cancer risk in mice with genetically impaired selenoprotein expression. The Journal of Nutrition, 136, 1311-1317.

Kikkert, J., \& Berkelaar, E. (2013). Plant uptake and translocation of inorganic and organic forms of selenium. Archives of Environmental Contamination and Toxicology, 65(2013), 458-465.

Killick, R., Eckley, I., \& Haynes, K. (2014). Changepoint: An R package for changepoint analysis. $\mathrm{R}$ package version 1.1.5. http://CRAN.R-project.org/package=changepoint.

Kiremidjian-Schumacher, L., Roy, M., Wishe, H. I., Cohen, M. W., \& Stotzky, G. (1994). Supplementation with selenium and human immune cell functions. Biological Trace Element Research, 41(1-2), 115-127.

Koivistoinen, P. (1980). Mineral element composition of Finnish foods: N, K, Ca, Mg, P, S, Fe, Cu, Mn, Zn, Mo, Co, Ni, $\mathrm{Cr}, \mathrm{F}, \mathrm{Se}, \mathrm{Si}, \mathrm{Rb}, \mathrm{Al}, \mathrm{B}, \mathrm{Br}, \mathrm{Hg}, \mathrm{As}, \mathrm{Cd}, \mathrm{Pb}$ and ash. Acta Agriculturae Scandinavica, 22, 15-25.

Koivistoinen, P., \& Huttunen, J. K. (1986). Selenium in food and nutrition in Finland. An overview on research and action. Annals of Clinical Research, 18(1), 13-17.

Kolmogorov, Y., Kovaleva, V., \& Gonchar, A. (2000). Analysis of trace elements in scalp hair of healthy people, hyperplasia and breast cancer patients with XRF method. $\mathrm{Nu}$ clear Instruments \& Methods in Physics Research, Section A: Accelerators, Spectrometers, Detectors, and Associated Equipment, 448, 457-460.

Larsen, E. H., Lobinski, R., Burger-Meÿer, K., Hansen, M., Ruzik, R., Mazurowska, L., \& Kik, C. (2006). Uptake and speciation of selenium in garlic cultivated in soil amended with symbiotic fungi (mycorrhiza) and selenate. Analytical and Bioanalytical Chemistry, 385, 1098-1108. 
Läuchli, A. (1993). Selenium in plants: Uptake, functions, and environmental toxicity. Botanica Acta, 106, 455-468.

Lavu, R. V., Du Laing, G., Van de Wiele, T., Pratti, V. L., Willekens, K., Vandecasteele, B., \& Tack, F. (2012). Fertilizing soil with selenium fertilizers: Impact on concentration, speciation, and bioaccessibility of selenium in leek (Allium ampeloprasum). Journal of Agriculture and Food Chemistry, 60, 10930-10935.

Lavu, R. V., Van de Wiele, T., Pratti, V. L., Tack, F., \& Du Laing, G. (2013). Bioaccessibility and transformations of selenium in the human intestine: Selenium-enriched crops versus food supplements. In G. S. Bañuelos, Z. Q. Lin, \& $\mathrm{X}$. Yin (Eds.), Selenium in the environment and human health (pp. 44-47). CRC Press.

Le Stum, H. (2011). Association Générale des Producteurs de Blé et autres céréales. IOP Publishing AGPB. http://www. agpb.fr/ fr/chiffre/recolte_monde.asp. Accessed December 13, 2011.

Li, N., Gao, Z. D., Luo, D. G., Tang, X., Chen, D. F., \& Hu, Y. H. (2007). Selenium level in the environment and the population of Zhoukoudian area, Beijing, China. Science of the Total Environment, 381, 105e111.

Li, H. F., McGrath, S. P., \& Zhao, F. J. (2008). Selenium uptake, translocation and speciation in wheat supplied with selenate or selenite. New Phytologist, 178, 92-102.

Lintschinger, J., Fuchs, N., Moser, J., Kuehnelt, D., \& Goessler, W. (2000). Selenium-enriched sprouts. A raw material for fortified cereal-based diets. Journal of Agricultural and Food Chemistry, 48(11), 5362-5368.

Longchamp, M., Angeli, N., \& Castrec-Rouelle, M. (2013). Selenium uptake in Zea mays supplied with selenate or selenite under hydroponic conditions. Plant and Soil, 362(1-2), 107-117.

Longchamp, M., Castrec-Rouelle, M., Biron, P., \& Bariac, T. (2015). Variations in the accumulation, localization and rate of metabolization of selenium in mature Zea mays 2 plants supplied with selenite or selenate. Food Chemistry, 182, 128-135.

Longnecker, M. P., Taylor, P. R., Levander, O. A., Howe, S. M., Veillon, C., McAdam, P. A., et al. (1991). Selenium in diet, blood, and toenails in relation to human health in a seleniferous area. American Journal of Clinical Nutrition, 53(5), 1288-1294.

Lonso, I. N. A., Mara, Ä., \& Lbarra, Y. O. M. A. (2004). Establishment of selenium uptake and species distribution in lupine, indian mustard, and sunflower plants. Journal of Agricultural and Food Chemistry, 52(4), 832-838.

Ma, W., Li, J., Ma, L., Wang, F., Sisák, I., Cushman, G., \& Zhang, F. (2008). Nitrogen flow and use efficiency in production and utilization of wheat, rice, and maize in China. Agricultural Systems, 99(1), 53-63.

Marschner, H. (1995). Mineral nutrition of higher plants (2nd ed., pp. 89-95). London: Academic Press.

Mayland, H. F., James, L. F., Panter, K. E., \& Sonderegger, J. L. (1989). Selenium in seleniferous environments. Environmental Science Sociéty, 23, 15-50

Mekonen, S., Lachat, C., Ambelu, A., Steurbaut, W., Kolsteren, P., Jacxsens, L., et al. (2015). Risk of DDT residue in maize consumed by infants as complementary diet in southwest Ethiopia. Science of the Total Environment, 511, 454-460.

Mombo, S., Foucault, Y., Deola, F., Gaillard, I., Goix, S., Shahid, M., et al. (2015). Management of human health risk in the context of kitchen gardens polluted by lead and cadmium near a lead recycling company. Journal of Soils and Sediments. doi:10.1007/s11368-015-1069-7.

Navarro-Alarcón, M., \& López-Martínez, M. C. (2000). Essentiality of selenium in the human body: Relationship with different diseases. Science of the Total Environment, 249, 347-371.

Nielsen, G. G. (1968). Loss of selenium in drying and storage of agronomic plant species - DTU Orbit. Plant and Soil, 32, 242-245.

Nuss, E. T., \& Tanumihardjo, S. A. (2011). Quality protein maize for Africa: Closing the protein inadequacy gap in vulnerable populations. Advances in Nutrition: An International Review Journal, 2(3), 217-224.

Okorie, A., Entwistle, J., \& Dean, J. R. (2012). Estimation of daily intake of potentially toxic elements from urban street dust and the role of oral bioaccessibility testing. Chemosphere, 86(5), 460-467.

Oomen, A. G., Hack, A., Minekus, M., Zeijdner, E., Cornelis, C., Schoeters, G., et al. (2002). Comparison of five in vitro digestion models to study the bioaccessibility of soil contaminants. Environmental Science and Technology, 36(15), 3326-3334.

Pierart, A., Shahid, M., Séjalon-Delmas, N., \& Dumat, C. (2015). Antimony bioavailability: Knowledge and research perspectives for sustainable agricultures. Journal of Hazardous Materials (in press).

Qian, Y., Chen, C., Zhang, Q., Li, Y., Chen, Z., \& Li, M. (2010). Concentrations of cadmium, lead, mercury and arsenic in Chinese market milled rice and associated population health risk. Food Control, 21(Suppl. 12), 1757-1763.

Qin, H., Zhu, J., Liang, L., Wang, M., \& Su, H. (2013). The bioavailability of selenium and risk assessment for human selenium poisoning in high-Se areas, China. Environment International, 52, 66-74.

Rayman, M. P. (2000). The importance of selenium to human health. Lancet, 356(9225), 233-241.

Rayman, M. P. (2008). Food-chain selenium and human health: Emphasis on intake. The British Journal of Nutrition, 100, 254-268.

Reilly, C. (1998). Selenium: A new entrant into the functional food arena. Trends in Food Science \& Technology, 9, 114-118. doi:10.1016/S0924-2244(98)00027-2.

Rosas-Castor, J. M., Guzmán-Mar, J. L., Hernández-Ramírez, A., Garza-González, M. T., \& Hinojosa-Reyes, L. (2014). Arsenic accumulation in maize crop (Zea mays): A review. Science of the Total Environment, 488-489, 176-187.

Shahid, M., Xiong, T., Masood, N., Leveque, T., Quenea, K., Austruy, A., \& Dumat, C. (2014). Influence of plant species and phosphorus amendments on metal speciation and bioavailability in a smelter impacted soil: A case study of food-chain contamination. Journal of Soils and Sediments, 14, 655-665.

Sharma, R. K., Agrawal, M., \& Marshall, F. M. (2009). Heavy metals in vegetables collected from production and market sites of a tropical urban area of India. Food and Chemical Toxicology, 47(3), 583-591.

Swartjes, F. A. (2011). Dealing with contaminated sites: From theory towards practical application (1st ed., p. 264). Berlin: Springer. 
Terry, N., \& Banuelos, G. S. (2012). Phytoremediation of contaminated soil and water (p. 408). Boca Raton: CRC Press.

Uzu, G., Sauvain, J. J., Baeza-Squiban, A., Riediker, M., Sánchez Sandoval, H. M., Val, S., et al. (2011). In vitro assessment of the pulmonary toxicity and gastric availability of lead-rich particles from a recycling plant. Environmental Science and Technology, 45(18), 7888-7895.

Wang, S., Liang, D., Wang, D., Wei, W., Fu, D., \& Lin, Z. (2012). Selenium fractionation and speciation in agriculture soils and accumulation in corn (Zea mays L.) under field conditions in Shaanxi Province, China. Science of the Total Environment, 427, 159-164.

Wang, D., Williams, B. A., Ferruzzi, M. G., \& D'Arcy, B. R. (2013). Microbial metabolites, but not other phenolics derived from grape seed phenolic extract, are transported through differentiated Caco-2 cell monolayers. Food Chemistry, 138(2-3), 1564-1573.

World Health Organization, Food and Agriculture Organisation and International Atomic Energy Agency expert group. (1996). Selenium. In: WHO (Ed.), Trace elements in human nutrition and health (pp 105-122). Geneva: WHO.

Wragg, J., Cave, M., Basta, N., Brandon, E., Casteel, S., Denys, S., \& Van de Wiele, T. (2011). An inter-laboratory trial of the unified BARGE bioaccessibility method for arsenic, cadmium and lead in soil. Science of the Total Environment, 409(19), 4016-4030.

Ximénez-Embún, P., Alonso, I., Madrid-Albarrán, Y., \& Cámara, C. (2004). Establishment of selenium uptake and species distribution in lupine, indian mustard, and sunflower plants. Journal of Agricultural and Food Chemistry, $52,832-838$.

Xiong, T., Leveque, T., Austruy, A., Goix, S., Schreck, E., Dappe, V., et al. (2014a). Foliar uptake and metal(loid) bioaccessibility in vegetables exposed to particulate matter. Environmental Geochemistry and Health, 36, 897-909.
Xiong, T., Leveque, T., Shahid, M., Foucault, Y., Mombo, S., \& Dumat, C. (2014b). Lead and cadmium phytoavailability and human bioaccessibility for vegetables exposed to soil or atmospheric pollution by process ultrafine particles. Americain Society of Agronomy., 43, 1593-1600.

Yang, G., \& Zhou, R. (1994). Further observations on the human maximum safe dietary selenium intake in a seleniferous area of China. Journal of Trace Elements and Electrolytes in Health and Disease, 8(3-4), 159-165.

Yu, Y., Luo, L., Yang, K., \& Zhang, S. (2011). Influence of mycorrhizal inoculation on the accumulation and speciation of selenium in maize growing in selenite and selenate spiked soils. Pedobiologia, 54(5), 267-272.

Zayed, A., Lytle, C. M., \& Terry, N. (1998). Accumulation and volatilization of different chemical species of selenium by plants. Planta, 206(2), 284-292.

Zhai, F. Y., \& Yang, X. G. (2006). Report on the situation of nutrition and health of Chinese residents: II. The status of diet and nutrient uptake in 2002. Beijing: People's Medical Publishing House (in Chinese).

Zhang, H., Feng, X., Jiang, C., Li, Q., Liu, Y., \& Gu, C. (2014). Understanding the paradox of selenium contamination in mercury mining areas: High soil content and low accumulation in rice. Environmental Pollution (Barking, Essex: 1987), 188, 27-36.

Zhang, Y., Pan, G., Chen, J., \& Hu, Q. (2003). Uptake and transport of selenite and selenate by soybean seedlings of two genotypes. Plant and Soil, 253, 437-443.

Zhao, L., Cox, A. G., Ruzicka, J. A., Bhat, A. A., Zhang, W., \& Taylor, E. W. (2000). Molecular modeling and in vitro activity of an HIV-1-encoded glutathione peroxidase. Proceedings of the National Academy of Sciences of the United States of America, 97(12), 6356-6361. 